\title{
Towards A New Regionalism in East Asia
}

\author{
Byeong-hae, Sohn \\ Kyung-pook National University
}

\begin{abstract}
The world trade order is undergoing transformation into a tripartite trading system owing to the growing regionalism in East Asia. East Asia has become progressively integrated as a trading bloc through intensified intra-regional trade. A powerful engine for this integration is concentrated FDI flows, which have contributed to the international production networking. The NIEs and the ethnic Chinese network have assumed a leading role in intra-regional trade integration. For further regional integration, it is necessary to depict an institutional integration scheme in line with the growing sense of new East Asian regionalism. However, it has to embrace not only East Asian identity but also open regionalism and inter-regionalism in considering the emerging global triad system.
\end{abstract}

- JEL Classification: F02, F15

- Key words: East Asia, East Asian identity, tripartite trading system, marketled integration, inter-regionalism

\section{Introduction}

Over the last few decades, East Asia has emerged as a market- driven economic integration through increasingly strong inter-dependency among East Asian economies. Since the financial crisis in 1997 East Asian economies have transformed this market-driven integration into institutional one based on a growing East Asian regionalism. Thereby, a new East Asia (EA hereafter) is emerging.

\footnotetext{
*Corresponding address: Byeong-Hae Sohn, School of Economics and Trade, Kyung-pook National University, 1370, Sangyuk-dong, Buk-gu, Daegu, Korea. Zip Code: 702-701. Tel: (82.53) 950-5432, Fax: (82.53) 950-5429, E-mail: bhsohn@knu.ac.kr

(C)2004-Center for International Economics, Sejong Institution, All Rights Reserved.
} 
The financial crisis provided a strong impetus for East Asian governments to consider formal economic integration. Their desire to establish their own regional institution was spurred by the fear of being marginalized in an increasingly uncertain global trading and financing system together with the widening and deepening of the integration of Europe and America. This growing regional consciousness has raised the hope of bring about a new East Asian community ${ }^{1}$ by way of institutional integration.

As a result, changes in this region have taken place in recent years. A number of formal trading arrangements such as the Japan-Singapore Economic Partnership Agreement (2002), the ASEAN-China Free Trade Area framework agreement (2002) and the institutionalization of the ASEAN plus Three (China, Japan and Korea) meeting have taken place. In addition to these movements towards institutional integration, a number of private arrangements for a production network centering on China as well as extended ethnic Chinese networks are reshaping the new EA.

If East Asian economies continue to deepen their market-led integration and can establish a region-wide institutional framework, EA might act as one of the pillar in the tri-polar trading system along with the EU and NAFTA. Therefore, the movement toward regional integration in EA will be of major significance in determining the future of the world trading system. If EA prefers to travel the regional route through discriminating trade arrangements, three major blocs would fragment the global market. On the other hand, if EA adopts open regionalism and leads inter-regionalism in relation with the EU and NAFTA, the tri-polar trading system will be sustained, thereby the world trading system will be stable.

In this sense, this paper tries to depict new form of East Asian regionalism being coexistent with the tri-polar system. In order to approach to this object, it first surveys the tri-polarization trend of world trade in Section II. It then examines the nature and causes of East Asian market integration in Section III. Although there are a lot of studies concerning the trade integration in EA (Rio 1995, Frankel 1997, and Yamazawa 1998 etc...), they did not pay much attention to the changing aspects of EA during the last decade such as concentration of foreign direct investments (FDIs) and the increasing role of the NIEs in regional trade and investment. However, these changing aspects may largely influence the further

${ }^{1}$ Jemal-ud-din Kassum, Vice president of the East Asia and Pacific region at the World Bank, emphasized recently the emergence of New East Asia in relation with the increasing regionalism in East Asia and with the rapid growth of China. Cf. World Bank (2003), P. 1-3. 
integration in EA especially from market-led integration to institutional one. Thus, Section III examines the market-led integration process in EA focusing on the concentrated FDIs flows and the changing role of the NIEs.

Lastly, in Section IV, it examines key factors that should be taken into account for new regionalism building in EA in relation to the world trading system. Concluding remarks are offered in Section V.

In this paper, EA is defined as a region covering the countries of Northeast Asia (mainland China, Hong Kong, Taiwan, South Korea and Japan) and Southeast Asia (ASEAN member countries). For analytical purposes, these are divided into four groups: Japan, newly industrializing economies (NIEs: Hong Kong, Korea, Singapore and Taiwan), ASEAN (Indonesia, Malaysia, Philippines, and Thailand) and Mainland China(China hereafter). North Korea, Brunei, and new members of ASEAN in Indochina (Cambodia, Laos, Myanmar, and Vietnam) have been excluded because their trade relationships with other countries have had relatively little importance until now.

\section{The Rise of Intra-Regional Trade in Tripartite Trading Blocs}

The spread of regionalism since the end of the Cold War has been represented by an increase in regionalization of world trade, centering especially on the three major trading blocs: the EU, NAFTA and EA.

Table 1 and Table 2 outline the main features of the trade regionalization around these three blocs for the period of $1978-2000^{2}$. Table 1 indicates intra-regional trade linkages of the three major trading blocs by means of the export dependent ratio $\left(R_{i j}\right)^{3}$. As seen in Table 1, the share of intra-regional exports in relation to the total exports of each trading bloc has continuously increased. The ratio of EA increased from 31 percent in 1978, to 43 percent in 1993, and to 48 percent in 2000. That of NAFTA increased from 36 percent in 1978 to 56 percent in 2000. The intra-regional export share of the EU also augmented from 57 percent to 62 percent during the same period.

\footnotetext{
${ }^{2}$ This paper is in debt to Tae Ho Bark (2000) in establishing the Table 1, 2 and 3 for the period of 1978-1998.

${ }^{3}$ Export dependent ratio $\left(R_{i j}\right)=x_{i j} / x_{i^{*}}$. Where, $x_{i j}$ : Exports from country $\mathrm{i}$ to country j. $x_{i^{*}}$ : Total exports of country i.

${ }^{4}$ Index of intensity in export $\left(I_{i j}\right)=\frac{x_{i j} / x_{i *}}{x_{* j} / x_{* *}}$. Where,

$x_{i j}$ : Exports from country i to country j. $x_{i *}$ : Total exports of country i.

$x_{* j}$ : World exports to country j. $\quad x_{* *}$ : World exports.
} 
Table 1. Intra-regional export dependent ratio $\left(R_{i j}\right)$ in major trading blocs

\begin{tabular}{lcccccc}
\hline & 1978 & 1988 & 1993 & 1996 & 1998 & 2000 \\
\hline EA & 0.31 & 0.36 & 0.43 & 0.49 & 0.43 & 0.48 \\
NAFTA & 0.36 & 0.41 & 0.46 & 0.48 & 0.51 & 0.56 \\
EU & 0.57 & 0.62 & 0.60 & 0.59 & 0.55 & 0.62 \\
\hline
\end{tabular}

Source: Direction of Trade Statistics, IMF.

Note, EA: China, Japan, 4 NIEs (Hong Kong, Korea, Singapore, Taiwan) and Four ASEAN members (Indonesia, Malaysia, Philippines, Thailand).

NAFTA: USA, Canada, Mexico. EU: 15 members of European Union.

Table 2. Index of intensity in intra-regional export $\left(I_{i j}\right)$ of major trading blocs

\begin{tabular}{lllllll}
\hline & 1978 & 1988 & 1993 & 1996 & 1998 & 2000 \\
\hline EA & 2.376 & 1.987 & 1.846 & 1.971 & 1.990 & 2.253 \\
NAFTA & 1.898 & 1.888 & 2.069 & 2.264 & 2.129 & 2.274 \\
EU & 1.344 & 1.469 & 1.585 & 1.588 & 1.415 & 1.736 \\
\hline
\end{tabular}

Source: Direction of Trade Statistics, IMF.

Table 2 shows the index of export intensity $\left(I_{i j}\right)^{4}$ of the three major trading blocs. According to this index, if trade is not geographically biased in the sense that the share of $i$ 's trade going to $j$ equals $j$ 's share in world trade, then it will have a value of unity $\left(I_{i j}=1\right)$. We can find in Table 2 the increasing tendency in general toward intra-regional trade integration during the last two decades, even in EA since 1993, though the index slightly fluctuated in 1998 for the case of the EU and NAFTA. That is, the intensity of intra-regional trade strengthened from 1.90 in 1978 to 2.07 in 1993 and to 2.27 in 2000 for NAFTA, from 1.34 to 1.59 and to 1.74 during the same period for the EU. So far as intra-regional trade in EA is concerned, the index $\left(I_{i j}\right)$ increased since 1993 after it had declined between 1978 and 1993, while the export dependent ratio $\left(R_{i j}\right.$, in Table 1$)$ in EA continuously increased. Thus, there has been a great deal of debates about whether or not EA had integrated into a single trading bloc during the last few decades. However, it is clear that EA has a net trend for intra-regional trade integration due to the increased trade intensity $\left(I_{i j}\right)$ since the early 1990s.

Like this, the regionalization of world trade that has led to the tri-polarization of the world trading system, has appeared clearly since the early 1990s. The strengthening of European integration and the new movement of American initiatives for regional integration in the Americas may be the main causes for this trend. However, the case of EA, where no regional arrangements take place, can be explained by other factors that have led to intra-regional trade integration. Let us examine then what led the intraregional trade integration in EA during the last few decades in the next section. 


\section{Main Contributors for Intra-Regional Trade in East Asia}

\section{A. Enlarged Connecting Role of The NIEs}

What are the main factors for integration of trade during the last decade in EA where no region-wide trading arrangement exists?

In order to determine the internal features of intra-regional trade in EA, lets first consider trade interdependence among East Asian countries by group (Japan, the NIEs, ASEAN and China) according to their level of industrialization. Table 3 explains the ratio of inter-group exports to their total exports. As shown in Table 3, intra East Asian trade has rapidly increased since the 1970s, except for China, whose export share to EA varied according to the year.

The most important fact in Table 3 is that the share of the NIEs in the total intraregional trade of EA progressively increased during the last three decades. Then the share of the NIEs in the total intra-regional trade of EA has become the largest since 1993. That is, the share of intra-NIEs exports in the total exports of the NIEs increased from 7.9 percent in 1970 to 15.6 percent in 2000, while the share of Japanese market in the NIEs' total export decreased from 11.8 percent to 8.9 percent. In the case of ASEAN, the share of the Japanese market in the total export of ASEAN decreased from 27.1 percent to 16.3 percent, while that of the NIEs' market increased from 17.5 percent to 25.2 percent in the same period. The share

Table 3. Intra-regional export dependent ratio $\left(R_{i j}\right.$, in percentage)

\begin{tabular}{llrrrrrrr}
\hline \multirow{3}{*}{ China } & 1970 & 1978 & 1988 & 1993 & 1996 & 1998 & 2000 \\
& Japan & 14.5 & 17.64 & 16.88 & 17.21 & 20.43 & 14.11 & 16.72 \\
& NIEs & 33.9 & 28.53 & 41.40 & 31.23 & 31.08 & 30.66 & 26.73 \\
& ASEAN & 5.9 & 3.29 & 2.78 & 2.65 & 3.36 & 2.77 & 3.75 \\
\hline \multirow{4}{*}{ Japan } & China & 2.9 & 3.13 & 3.58 & 4.79 & 5.31 & 5.26 & 6.36 \\
& NIEs & 13.7 & 15.39 & 18.80 & 22.30 & 24.68 & 20.22 & 24.03 \\
& ASEAN & 7.2 & 6.49 & 4.91 & 9.07 & 12.42 & 8.27 & 9.51 \\
\hline \multirow{6}{*}{ NIEs } & China & 0.5 & 0.2 & 8.1 & 13.5 & 14.0 & 15.0 & 17.69 \\
& Japan & 11.8 & 12.9 & 12.4 & 8.7 & 9.3 & 6.9 & 8.89 \\
& NIEs & 7.9 & 8.4 & 10.7 & 14.7 & 15.8 & 13.4 & 15.56 \\
& ASEAN & 9.6 & 8.0 & 6.3 & 8.6 & 10.9 & 9.9 & 10.26 \\
\hline \multirow{6}{*}{ ASEAN } & China & 0.5 & 0.8 & 2.2 & 2.3 & 3.0 & 3.1 & 3.51 \\
& Japan & 27.1 & 29.4 & 24.6 & 19.1 & 17.8 & 13.1 & 16.32 \\
& NIEs & 17.5 & 16.1 & 21.0 & 24.4 & 25.8 & 23.7 & 25.23 \\
& ASEAN & 2.4 & 3.2 & 3.6 & 4.4 & 6.3 & 6.5 & 7.15 \\
\hline Source
\end{tabular}

Source: Direction of Trade Statistics, IMF. Monthly Statistics of Exports and lmports, Taiwan Area, Ministry of Finance, The Republic of China. 
of the NIEs in Japanese exports also expanded from 13.7 percent to 24.0 percent.

These evolving patterns of intra-regional trade flows indicate that the NIEs, as a group, have become more and more important market for East Asian countries' exports, while the absorbing role of the Japanese market, which was the most important market in the past, has declined during the last two decades.

In spite of the increasing dependence on regional markets, the dependent ratio between China and ASEAN, and intra-ASEAN trade has been insignificant until now, although it has slightly increased since the second half of the 1990s. It is clear from these changed intra-regional trade flows that the trade integration in EA has been mainly led by the NIEs. That is, the NIEs have assumed the leading role in intra-regional trade integration, replacing Japan that was the main contributor to regional trade in the past. $^{5}$

\section{B. Intra-regional FDI flows}

\section{Concentrated FDI flows within East Asia}

Secondly, it should be noted that foreign direct investment (FDI), first by Japan and then by the NIEs, has largely contributed to the intra-regional trade integration during the last few decades.

Until the end of the 1980s the most important player in investment flows in EA was Japan. Japan's cumulative foreign investment stock between 1951 and 2001 accounted for 111,624 billion Yen, of which 17.5 percent have been invested in Asia (Appendix Table 1). Japan's postwar investment in EA has gone through several stages reflecting the shift of comparative advantage to the developing countries (Rao, 1995). Before the late 1970s, it was mainly in the resource sectors in ASEAN. However, from the late 1970s to the second half of the 1980s, it grew sharply in the manufacturing sectors in the NIEs. The third wave was the surge after the Plaza Accord in 1985. The rise of production cost in Japan after the exchange-rate realignment in 1985 and the rise of wage cost in the NIEs through the 1980s led to the shift of production site to lower-cost ASEAN countries. The most recent wave took place in China in the middle of the 1990s (Table 4).

Approximately half of Japanese investments in East Asian developing countries until the end of 2001 were in manufacturing sectors (49.2 percent in Asia, 53.8

\footnotetext{
${ }^{5}$ Diminishing role of Japan in East Asian trade integration during the 1980s has been approved also in various gravitational analyses. According to Frankel's (1997) study, East Asian trade integration has mainly resulted from rapid economic growth of East Asian countries. Japanese role in trade integration is not significant but its role is important in financial integration in EA.
} 
Table 4. Japan's FDI flows in East Asia, by sub-region. (Millions of US dollars, percentage)

\begin{tabular}{ccccccccc}
\hline & \multicolumn{2}{c}{ NIEs 4 } & \multicolumn{2}{c}{ ASEAN 4 } & \multicolumn{2}{c}{ China } & \multicolumn{2}{c}{ EA, Total } \\
\cline { 2 - 9 } & Sum, B & B/A & Sum, C & C/A & Sum, D & D/A & Sum, A & $\%$ \\
\hline $1951-69$ & 120 & 25.3 & 353 & 74.6 & 0 & 0.0 & 473 & 100.0 \\
$1970-79$ & 3,070 & 38.2 & 4,946 & 61.6 & 14 & 0.2 & 8,030 & 100.0 \\
$1980-84$ & 3,765 & 40.7 & 5,307 & 57.4 & 173 & 1.9 & 9,245 & 100.0 \\
$1985-89$ & 12,993 & 58.5 & 6,927 & 31.2 & 2,286 & 10.3 & 22,206 & 100.0 \\
$1990-94$ & 12,764 & 36.7 & 15,808 & 45.4 & 6,254 & 18.0 & 34,826 & 100.0 \\
$1997-01^{(1)}$ & 12,068 & 37.2 & 14,848 & 45.7 & 5,550 & 17.1 & 32,466 & 100.0 \\
\hline
\end{tabular}

Source: The ministry of Finance, Japan, Annual Report of the International Finance, for 1951-89, and OECD, International Direct Investment Statistics Yearbook, for 1990-94. JETRO, Investment White Paper, for 1997-2001.

Note: (1), Up to the first half of 2001.

Amounts; notification base, cumulative value in each period. Japanese investment in China in 1995 was exceptionally great with unknown reason so the table expressed the recent five years amounts during 1997-01 in omitting the amount of 1995-96.

percent in ASEAN and 66.1 percent in China; Appendix Tables 1). One-fifth of that was in electronics, mechanical and auto-concerned sectors, which can be produced through international production chains. This pattern of investment would have important implications for increasing relation between FDIs and trade within the region.

On the other hand, since the mid-1980s, the NIEs have become leading regional capital suppliers along with Japan, due to current account surpluses and rises in wages. That is, the NIEs have taken industrial re-structural action by increasing FDIs in neighboring developing countries since the middle of the 1980s. More than half of their total FDI was invested in EA, mainly in ASEAN countries and China (Appendix, Table 2) ${ }^{6}$. The NIEs have replaced the USA and Japan as the largest foreign investors in ASEAN and China since the end of the 1980s (Rao Narhari 1995, p.113 and Table 5). Thus, from the second half of 1980s, the NIEs became the most important actors in intra-regional investment. This shift from Japan to the NIEs as the main actors in FDI flow in developing countries is significant for the regional division of labor. It means that the spectrum of intraregional division of labor is largely expanding from inter-industry to intra-industry specialization through the NIEs' investment in developing economies.

${ }^{6}$ The most important part of NIEs investments in EA was in manufacturing sectors. For the case of Korea, about 53 percent of total cumulative investments at the end of 2001 were in manufacturing sectors ( 84 percent in China and 65 percent in ASEAN). About 34 percent of Taiwanese cumulative FDI stock between 1952 and 2002 were in manufacturing sectors(The Export-Import Bank of Korea, 2002 and Board of Economic Planning and Development, Taiwan, 2003). 
Table 5. FDI inflows in China by origin (Cumulative stock, 1979-1994 and 1995-2001, millions of US dollars)

\begin{tabular}{lcccc}
\hline \multirow{2}{*}{ Country } & \multicolumn{2}{c}{$1979-1994$} & \multicolumn{2}{c}{$1995-2001$} \\
\cline { 2 - 5 } & Amounts* & Percentage & Amounts* & Percentage \\
\hline Hong Kong & 58,109 & 60.76 & 129,677 & 42.96 \\
Taiwan & 8,447 & 8.83 & 20,780 & 6.88 \\
U.S.A. & 7,732 & 8.08 & 26,920 & 8.92 \\
Japan & 7,326 & 7.66 & 24,933 & 8.26 \\
ASEAN(5) (Singapore) & 3,527 & 3.68 & $22,508(17,077)$ & $7.46(5.66)$ \\
Korea & na & na & 11,498 & 3.81 \\
Others & 10,496 & 10.97 & 65,527 & 21.70 \\
Total & 95,637 & 100.00 & 301,843 & 100,00 \\
\hline
\end{tabular}

Source: Statistical Yearbook of China, 1979-2002.

Note: ASEAN(5), refers to Indonesia, Malaysia, the Philippines, Singapore, and Thailand.

Amounts*, based on foreign capital actually used by country.

Since the second half of the 1980s, ASEAN countries have also started to invest in China, and their share of the total FDI into China increased from 1.1 percent in 1988 to 5.5 percent in 1994(JETRO, 1996) and about 7.5 percent in the second half of the 1990s (Table 5). As a result, East Asian countries' share of the total FDI inflows into China still represents about 70 percent (Table 5).

In this way, East Asian countries' FDI flows have formed a concentrated and an overlapping investments pattern between Japan, NIEs, ASEAN, and China. These concentrated investments have contributed to the international production networking that has resulted in the increase of intra-regional trade.

\section{International production inducement effects}

This wave of FDI flows must have brought about intensified intra-regional trade in the form of intra-industry trade for intermediate goods. For example, the flow of Japanese FDI to the NIEs increased Japanese exports of machinery and equipment to the NIEs. Similarly, the investment of the NIEs to ASEAN and China led to increased exports of intermediate goods from the NIEs to these host countries. We can indirectly confirm these investment-trade relations in Table 6, which represents the induced production coefficient ${ }^{7}$ in the home country (country group on column in Table 6), caused by additional production of final goods in the host

${ }^{7} \mathrm{~A}$ coefficient of induced production indicates the ratio of increase in the total domestic out-put (in intermediate products) in country A per additional unit of final demand generated in country B (in a particular industrial sector). 
Table 6. International Input-Output Relations among East Asian countries

\begin{tabular}{ccccccc}
\hline \multirow{4}{*}{1985} & & NIEs (B) & Japan & ASEAN & China & ROW \\
\cline { 2 - 7 } & NIEs (A) & 1.841546 & 0.011371 & 0.041822 & 0.004403 & 0.009206 \\
& Japan & 0.118226 & 2.135399 & 0.102385 & 0.050611 & 0.019997 \\
& ASEAN & 0.052498 & 0.020104 & 1.603467 & 0.006597 & 0.005268 \\
& China & 0.019619 & 0.014915 & 0.011510 & 2.125423 & 0.002245 \\
& ROW & 0.100358 & 0.041612 & 0.056907 & 0.018120 & 2.046331 \\
\hline \multirow{4}{*}{1990} & NIEs & Japan & ASEAN & China & ROW \\
\cline { 2 - 7 } & NIEs & 1.853532 & 0.013145 & 0.067950 & 0.016369 & 0.010888 \\
& Japan & 0.123208 & 2.072350 & 0.125844 & 0.035856 & 0.020177 \\
& ASEAN & 0.035843 & 0.013873 & 1.603683 & 0.011975 & 0.004167 \\
& China & 0.007532 & 0.011112 & 0.015134 & 2.371034 & 0.003053 \\
& ROW & 0.102379 & 0.035147 & 0.048306 & 0.026558 & 1.937986 \\
\hline \multirow{4}{*}{1995} & NIEs & Japan & ASEAN & China & ROW \\
\cline { 2 - 7 } & NIEs & 1.389688 & 0.009348 & 0.049097 & 0.026955 & 0.010534 \\
& Japan & 0.088974 & 2.035462 & 0.124779 & 0.057068 & 0.025626 \\
& ASEAN & 0.036358 & 0.011958 & 1.580832 & 0.014543 & 0.008106 \\
& China & 0.023272 & 0.000904 & 0.017426 & 2.317622 & 0.005601 \\
& ROW & 0.073980 & 0.028443 & 0.055890 & 0.030112 & 2.016132 \\
\hline
\end{tabular}

Source : Institute of Developing Economies, Asian International Input-Output Table 1995, JETRO, 2001, Japan.

Note: Coefficient of induced production of intermediate goods in country group A on column, caused by additional production (one unit) of final goods in country group B on line. ROW: Rest of world.

country (country group on line in Table 6$)^{8}$.

We can verify, as shown in Table 6 , that induced production coefficients of developing countries (ASEAN and China, main host countries of FDI), relative to industrialized countries (Japan and NIEs, main home countries of FDI) are distinctly higher than those of the inverse case. This means an expansion of final demand in host countries induces increased imports of intermediate goods from home countries. Additionally we can see a certain positive correlation between the wave of FDI flow and international production effect as follows:

The NIEs and ASEAN, as the main host countries of Japanese investment until the end of the 1980s, have had relatively high inducement effect on Japanese domestic production. However, the effect of the NIEs production on Japanese

\footnotetext{
${ }^{8}$ In order to study investment- trade relations and the industrial interdependence between trading partners, this paper referred to the linked international input-output tables between East Asian countries, "Asian International Input-Output table, 1995", established by the Institute of Developing Economies (IDE), JETRO, 2001, Japan. The I/O table for 2000 is undergoing establishment by the IDE, so, this paper referred to the tables of 1985,1990 and 1995.
} 
intermediate goods, decreased while that of ASEAN increased from 1985 to 1995. This change accords with the shift of Japanese investment priority from the NIEs to ASEAN between the second half of the 1980s and the mid-1990s. The same trend is apparent in case of China. The inducement effect of Chinese final products over the NIEs' domestic intermediate production greatly strengthened from 0.0044 in 1985 to 0.0163 in 1990 and to 0.2695 in 1995 , following the mass investment by the NIEs into China since late 1980s. The effect of Chinese final products on Japanese domestic production also increased from 0.0356 to 0.0571 between 1990 and 1995 according to the increasing Japanese investment during the same period (Table 4). The relation between China and ASEAN reveals the same trend as the others after the launching of ASEAN's investment in China since the beginning of the 1990s.

These mutations of international production correlation, observed by means of international linked input-output tables, are broadly correlated with the wave of FDI flows during the last two decades, although there is a slight time lag between investment and production effect.

Therefore, it is worthwhile to assume that FDI has served as an accelerator not only in the host countrys production, but also in the home country's inputs production, which is used to produce final products in the host country. This is why the concentrated FDI has induced intra-regional trade and also the reason for the emergence of EA as a natural trading bloc.

\section{The Role of the Ethnic Chinese network}

Lastly, we can note that the ethnic Chinese network has brought about wider effects of intra-regional investment and of new regionalism in EA. Although no firm data are available, estimates of the overseas Chinese population in EA range from fifty-five to sixty million, half in ASEAN and the other half in the NIEs. They form a collection of tight knit clans bonded by common roots and language in the original area of migration (Yu, 2000).

With the opening up of China, these overseas Chinese have established business relations with Mainland China based on language and historical bonds. Especially, trade and investment links between Hong Kong and Guangdong, and between Taiwan and Fujian have grown rapidly in the 1980s. This linkage has resulted in the development of Southern China Economic Zone, which connects intraregional investment and trade in EA. This is the reason why the ethnic Chinese states - Hong Kong, Taiwan, Singapore, and other ASEAN countries to some 
extent - take the most important shares of the total FDI inflow into China (about 57 percent in the second half of the 1990s) as shown in Table 5. It also partly explains why the NIEs (Hong Kong, Singapore, and Taiwan) play the major role in connecting trade and investment in the region.

\section{For Further Regional Integration in East Asia}

\section{A. Institutionalization of Regional Cooperation}

\section{Institutional approaches for regional cooperation}

EA is leading to a new phase of regional integration backed by the abovementioned increasing intra-regional trade and investment on the one hand, and by the increasing new regionalism in and outside the region. A key question to be asked at this point is whether EA should pursue an institutional integration route or keep market oriented natural integration. There were a lot of debates on this question in the past. But the aftermath of the financial crisis in 1997 and a growing sense of East Asian regionalism after the crisis demonstrated the need for institutional approach in order to manage existing market-led integration and to cope with external economic shock on the regional level (Bergsten, 2000).

Thus East Asian countries have held summit meetings under the ASEAN-plusthree (10 ASEAN members, China, Japan, and Korea) since 1997. Its economic ministers are starting to gather annually. The central banks of the region have met regularly since the early 1990s, and have established a currency-swap agreement with each other. The Japan-Singapore Economic Partnership Agreement has recently gone into effect. ASEAN-China has concluded a framework agreement for free trade area(FTA), Japan-Korea FTA and Korea-Singapore FTA are being officially considered. Much more ambitious ideas such as East Asian FTA and China-Japan-Korea FTA are also being contemplated (KIEP and JETRO, 2000 and KIEP, 2003). These moves to enhance regional cooperation through intergovernmental agreement can be seen as a step toward institutional approach as well as an expression of growing regionalism in EA.

\section{Constraints and possibilities of institutional approach}

In spite of the growing regionalism in recent years, there are a number of difficulties that restrain the institutional approaches for regional cooperation in EA. In terms of economics, difference in economic system, disparity in the level of economic 
development, and resistance to the structural adjustment in sensitive industries may be regarded as potential constraints for institutional integration in this region.

In addition to these economic aspects, East Asian countries face with several historical and political hindrances as well as security issues. That is, different view on history and the remnants of historical animosity, especially in Northeast Asia, do not help building mutual trusts necessary to create institutional integration. The integration process may also face with difficulties of the absence of strong leadership for regional integration in addition to the hegemonic struggle between two super powers, China and Japan. Furthermore, the actual situation of East Asian cooperation is compounded by the interrelation between economic and security structures. In consider-ing these complicated aspects, it would be naive to expect a smooth ride for region-wide institutional integration.

These difficulties, nevertheless, should not necessary lead to a pessimistic view on East Asian regional integration. The historical and political hindrances may be gradually dissolved during a patient process of regional cooperation as we can see in the case of European integration since the World War(II). The obstacle concerned with different economic system has been largely mitigated by open door and liberaliza-tion policies in socialist countries since the end of the Cold War. Increasing economic and social interdependence among East Asian counties will contribute to reduce the gaps in their views on historic issues. The security issues may also be handled in linkage with economic assistance as we have seen in the case of Korean Peninsula Energy Development Organization (KEDO). The absence of leadership for regional integration and the hegemonic struggle between China and Japan could be coordinated somewhat by means of "regionalism building through interregionalism", which will be examined in the next section.

In this sense, an institutional approach, which is able to concrete the closer economic interdependence among neighboring countries, may be one major stream of solutions that can be problem shooting in EA. "The ASEAN plus three" process for institutional cooperation since the financial crisis has become one of the most promising movements in this context.

Considering all of these positive factors, East Asian regional cooperation appears to increase the prospects of institutional approaches, while their existing obstacles are likely to be mitigated. 


\section{Implications of increasing trade integration and role of the NIEs for institutional integration}

Then, what are the implications of the increasing market led integration and increasing role of the NIEs in intra-regional trade and investment as confirmed in previous sections for further regional integration in EA?

In the static aspect, the increasing market led integration (de facto integration) would be a supporting base for institutional integration (de jure integration). If institutional integration such as the East-Asian Free Trade Area (EAFTA) is formed in EA, its trade creation is likely to be great while trade diversion is small.

Because the major trading partners are already natural trading partners owing to the existing market-led integration. ${ }^{9}$ This will also lead to further trade integration, because diversity in industrial structures among East Asian countries results in the complementary regional division of labor that may be linked closely by institutional free trade arrangement. In this sense, the market led integration in EA can be regarded as a favorable precondition for institutional integration.

On the other hand, EA, as a group, has emerged as a trading bloc since the 1970s through the intensification of intra-regional trade, the main connector of which was Japan, the most advanced country in the region. Thus, the East Asian trading bloc can be represented as an asymmetrical integration in the form of "hub and spokes" in which trade gains were distributed in favor of the hub country. However, ongoing trade integration is mainly being generated by the NIEs. As a result, the intra-regional trade pattern is shifting progressively, to some extent, from vertical to horizontal, and from inter-industry to intra-industry trade that may lead an equalization of trade gains between trading partners. This also means an expansion of the trade spectrum between advanced countries and developing countries in manufacturing sector. Therefore, the increased connecting role of the NIEs as well as the market led natural integration could be regarded as an important condition for region-wide institutional integration in EA.

\section{B. Ideal East Asian Regionalism}

Then, what should be considered for a desirable form of East Asian regionalism in which institutional mechanism would be mapped out? In considering the growing regionalism in EA as well as the increasing importance of EA in the global trading system, East Asian regionalism should embrace the following key

${ }^{9}$ In this sense, the institutional economic integration in EA could not be harmful to amelioration of world welfare. 
concepts: "Regional identity", “open regionalism", and "regionalism through inter-regionalism". The first term represents a regional factor that enables East Asian countries to integrate with others. The second represents a condition for the development of global free trading order. The last may be used not only to bridge the link among the global triangle - EA, the EU, and NAFTA -- but also to bridge the link between sub-regional groupings within EA.

\section{Regionalism led by Regional Identity}

The identity of a region is strategically important in regional integration. In EA, the concept of East Asian identity began to gain political attention beginning in the 1990s (Lee Geun, 2000, p.72).$^{10}$ The concept of an East Asian identity ${ }^{11}$ is not yet defined in economic literature, but it can be found in terms of Asian values, stemming from East Asian cultural common denominators especially from Confucian ethics.

Most of the East Asian nations (Japan, Korea, China, Taiwan, Hong Kong, Singapore, and Vietnam) have been strongly influenced by Confucian culture. Confucianism has been a very powerful socio-cultural force in all these countries for over two thousand years. It stresses the importance of thrift, hard work, selfdiscipline, and education. Together these factors are the key variables in explaining the economic performance of East Asian economies during the last several decades (Ju, Sung Whan 2000, Wang, Russell and Tan, 2000).

East Asian countries have sympathized with each other because of this Asian common socio-cultural denominator, ${ }^{12}$ when faced with globalization advanced by American initiative since the end of the Cold War. The traditional value of economic activities in EA is rooted in social obligation that emphasizes the group or community. This value stands in direct contrast to the American neo-liberal approach associated with globalization that emphasizes the maximization of individual interest (Stubbs 1998. P.70). Thus, the globalization and the resulting collapse of economic space in international transactions challenge these Asian socio-cultural values, which are mainly founded on Confucian values (Sohn 2002. p.

\footnotetext{
${ }^{10}$ Asian political leaders, Former Prime Minister of Singapore, Lee Kuan Yeu, and former Prime Minister of Malaysia, Mahatir Mohamad have stressed East Asian identity based on Asian Value in the face of globalization pressure.

${ }^{11}$ Interpretation of Asian Value varies between individual advocates and official government ideologies, ranging from Chinese Confucian values to ideals of centralized regimes such as Singapores authoritarian regime. The concept in this paper mainly refers to Confucian values.

${ }^{12}$ In addition to the Confucian ethic, individual thought based on Taoism and Buddhism as well as the common use of Chinese character in practice form the basis of Asian socio-cultural denominator.
} 
173), and on Taoism to some extent. ${ }^{13}$ As a result, a number of East Asian countries have sought to forestall attempts to impose a neo-liberal version of globalism on EA by launching a new East Asian regionalism with regional integration scheme.

In this sense, it is necessary to further develop East Asian identity and to respect Asian way ${ }^{14}$ backed up by common cultural denominator in depicting new East Asian regionalism.

\section{Open Regionalism}

However, if EA prefers to travel the regional route, which can be characterized by inward-looking regionalism under the slogan of Asian way, the world trading system would be faced with a confrontational triad of economic blocs: European, East Asian, and the North American trading blocs. Insofar as the world economy is divided into three discriminating trading blocs, the world economic system might deteriorate with respect to maximization of global welfare, as Paul Krugman indicated (Paul Krugman, 1993). EA, as one of the three principal axes of the world economy, is obliged to maintain open regionalism in order to avoid exclusive fragmentation of world markets. Instead, EA needs to ask the West to respect the achievement of East Asian regionalism and to yield fair ground to share in the emerging three block trading system. EA has long been suppressed by a world system that continues to be dominated by the Western powers in spite of East Asia's economic performance and time-honored cultural heritage (A.G. Frank 1998, in Preface, Korean edition 2003).

However, open regionalism in this case means a regionalism that is characterized by the outward-looking nature of economies and an openness of regional integration system respecting the article 24 of the GATT/WTO, while promoting free movement of goods, service, and capital within the region. Nevertheless, East Asian open regionalism might be ineffective in a world of increasing inward oriented

\footnotetext{
${ }^{13}$ In order to understand Asian traditional thought, it is necessary to consider Confucianism and Taoism as both sides of a coin. Confucianism represents an official idea and social ethics while Taoism represents a thought of a private individual. Thus, most of the scholars used to regard Confucianism as a basic thought being able to explain the community oriented social development and the government led economic development in EA. cf. Lee, Ho-Chul and Mary P. McNulty (2003), and Mazshida Takahiro (1982).

${ }^{14}$ In this paper, Asian way means a way of regional cooperation based on East Asian common cultural denominators, which are not dependent on western initiatives. A. G. Frank (1998) has indicated recently, in his preface of Korean edition of the book titled "Re Orient", that there is real difference between the western society and Asians one, and he stressed to keep an Asian way, not influenced by western methods, in socioeconomic policy decision and in external policy making vis-à-vis the western capitalist.
} 
regionalism. Therefore, it is necessary to introduce a kind of inter-regional coordination framework that manages open regionalism and balanced relations among the Triad regions.

\section{Regionalism through inter-regionalism}

Lastly, we would stress inter-regionalism that bridges the link among the tripartite trading groups or the link between sub regional groupings within EA.

East Asian countries may use this kind of inter-regionalism as a means to enhance East Asian regionalism as well as to materialize its openness (H. Häggi, 1999). By participating in a region-to-region dialogue such as Asia Europe Meeting (ASEM), East Asian countries are able to portray themselves as representing the third pole in the North America, Europe, and EA triangle. In fact, they have been driven to organize themselves on a regional basis by the ASEM process since 1996. In this way, inter-regionalism offers an opportunity to East Asian countries to get together without arousing anxiety in other parts of the Triangle.

On the other side, inter-regionalism may offer China and Japan the possibility to influence the future development of East Asian regionalism in accordance with their own interests. For example, China is interested in using ASEM as a way to neutralize American influence, whereas Japan aims at maintaining full transparency of the ASEM process to the USA (H. Häggi 2003, pp. 211-213). Thus, China and Japan as the most powerful actor in regionalism building in EA cannot help but interested in regional cooperation in the face of the inter-regional endeavor.

Inter-regionalism has the advantage of diluting somewhat the overwhelming position, which a super power - either China or Japan - has in regional context. It can be distinguished also to promote open regionalism through inter regional cooperation and mutual dialogue between the major trading partners. In this sense, inter-regionalism may be served as a training ground for East Asian regionalism.

\section{Concluding Remarks}

A powerful engine for trade integration in EA is concentrated FDI flows that induce the intra-regional trade among East Asian countries. The NIEs, replacing Japan, have become the most important connector in intra-regional trade since the beginning of 1990s. The ethnic Chinese networks have played the role of 
accelerators of regional trade integration. These are of great significance not only in expanding intra-regional division of labor, but also in deepening and reshaping the East Asian integration.

In addition to these factors, the potential for further regional integration in EA is still enormous since the scope of regional division of labor is expanding in accordance with the dynamic growth of developing countries and with their trade liberalization policies. In order to realize this potential for further regional integration, a kind of institutional scheme including trade liberalization measures needs to be introduced.

The institutional scheme for EA, however, should be mapped out on the basis of Asian identity, open regionalism, and inter-regionalism. That is, EA must inquire into the concept of its regional identity that enables East Asian countries to integrate with each other. EA, as one of the three principal axes of the world economy, however, must take into account its openness to outside the region in order to manage the stable tripartite trading system. And EA needs to respect interregionalism so as to realize its openness on the one hand and to promote new regionalism building in EA including two super powers, China and Japan on the other hand. This kind of regional system can allow regional countries to keep abreast of the changing global trading order as well as to advocate a regional consciousness with the onslaught of globalization based on neo-liberalism.

Received 24 November 2003, Accepted 12 February 2004

\section{References}

Bark, Tae-Ho (2000), "Trade Patterns of East Asia: Before and After the Currency Crisis," Journal of International and Area studies, 7(1): 1-14.

Bergsten, Fred C. (2000), The New Asian Challenge, Working Paper, No. 00-4, Institute for International Economics (I.I.E.), Washington, DC, March.

Board of Economic Planning and Development (2003), Taiwan Economic Forum, Vol. 1, N0.8, Republic of China.

China Statistics Publishing Co., Statistics Yearbook of China, 1979-2002, Peking.

Do Zuauen (1998), Gajin keizaiken to Nippon [Chinese Economic Area and Japan], Yousinto, Tokyo (in Japanese).

Export-Import Bank of Korea (2002), Overseas Direct Investment Statistics Yearbook, Seoul.

Frank, Andre Gunder (1998), ReOrient: Global Economy in the Asian Age, University of California Press (Korean edition, translated by Yeesan Publishing Co., Seoul, published in 2003), pp.15-28. 
Frankel J.A. (1997), Regional Trading Blocs in the World Economic System, Institute for International Economics (IIE), Washington, D.C.

Hanggi Heiner (2003), regionalism through inter-regionalism in Fu-Kuo, Liu and P. Regnier, (eds.), Regionalism in East Asia, Paradigm shifting? Routledge, London, 197-219.

(1999), ASEM and the construction of the new Triad, Journal of the Asia Pacific Economy, 4(1): 56-80.

Institute of Developing Economies (2001), Asian International Input-Output Table 1995, IDE Statistical Data series No.82, JETRO, 2001, Japan.

IMF, Direction of Trade statistics, every year.

JETRO (1998, 2000, 2002), Investment White Paper, Tokyo. (1996), Chinese Economy, Tokyo.

JETRO and KIEP (2000), Toward a Korea-Japan FTA: Assessments and Prospects, Joint Symposium between Korea Institute for International Economic Policy (KIEP) and Institute for Developing Economics, JETRO, May, Seoul.

Ju, Sung-Whan (2000), The Economic Development Models and the Confucian Market Economy Model of East Asia, Global Economic Review, 29(3): 98-118.

KIEP (2003), World Economy Update, No. 3-39, Oct.9, 2003, Seoul.

Krugman, Paul (1993), "Regionalism versus Multilateralism: analytical notes." J. de Melo and A. Panagariya (eds.), New Dimension in Regional Integration, Cambridge University Press, Cambridge, 61.

Lee, Ho-Chul and Mary P. McNulty (2003), East Asias dynamic development model and the Republic of Korea's Experiences, World Bank Policy Research Working paper, 2987 (March).

Lee, Geun (2000), Implications of Asian Value Discourse on ASEM, Global Economic Review, 29(1): 67-78.

Liu, Fu-Kuo and P. Regnier (2003), Regionalism in East Asia, Paradigm shifting? Routledge, London.

Mazshida Takahiro (1982), History of East Asian Thought, binsan shoten, Tokyo. (Korean edition, translated by Cho, sung-ul, Han-oul Publishing Com., Seoul, 2000).

Ministry of Finance (2002), Statistics Monthly, No.608, Dec., Japan.

OECD (1999-2002), International Direct Investment Statistics Yearbook, Paris.

Rao, Narhari (1995), Intra-Asian trade: Trends and Prospects, in Kiichiro Fukasaku (ed.), Regional Cooperation and Integration in Asia, OECD, Paris, 99-136.

Sohn, Byeong-Hae (2002), Regionalization of Trade and Investment in East Asia and prospects for Further Regional Integration, Journal of the Asia Pacific Economy, 7(2): $160-180$.

Stubbs, Richard (1998), Asia-pacific regionalism versus globalization, in W.D. Coleman and G.R.D. Geoffrey, (eds.), Regionalism and Global Economic Integration, Routledge, London, 68-80.

Wang, Jinguo, Russell Smyth, and Tan (2000), The role of Confucian values in East Asian development: before and after the financial crisis, Journal of International and Area 
studies, 7(1): 115-135.

World Bank (2003), A New East Asia, DevNews Media Center, May 9. (http:// www.worldbank.org/WBSITE/EXTERNAL/NEWS)

Yamazawa, Ippei (1998), Economic Integration in the Asia Pacific Region in Graham Thompson, (ed.), Economic Dynamism in the Asia-Pacific, Routledge, New York, 163-184.

Yu, Chukun (2000), Ethnic Chinese: Their Economy, Politics and Culture, Japan Times, Tokyo. 
Appendix 1. Japanese foreign direct investment, by region and by industry (Cumulative stock, 1951-2001, percentage)

\begin{tabular}{|c|c|c|c|c|c|c|c|c|}
\hline \multirow{2}{*}{\multicolumn{2}{|c|}{ Industry }} & \multirow{2}{*}{ World } & \multirow{2}{*}{ NAFTA } & \multirow{2}{*}{ EU } & \multirow{2}{*}{ Asia } & \multirow{2}{*}{ ASEAN4 } & \multirow[b]{2}{*}{ China } & \multirow[b]{2}{*}{ NIEs4 } \\
\hline & & & & & & & & \\
\hline \multicolumn{2}{|c|}{ Manufacturing } & 32.2 & 34.3 & 27.6 & 49.2 & 53.8 & 66.1 & 37.0 \\
\hline & $\begin{array}{l}\text { Electronics, } \\
\text { Machinery, } \\
\text { Automobile. }\end{array}$ & 16.0 & 19.2 & 14.8 & 21.0 & 20.5 & 33.4 & 16.5 \\
\hline \multicolumn{2}{|c|}{ Agriculture, Fishing, Mining } & 5.3 & 1.8 & 2.4 & 12.1 & 25.9 & 0.9 & 0.5 \\
\hline \multicolumn{2}{|c|}{ Services } & 60.8 & 63.1 & 68.2 & 36.2 & 18.6 & 30.5 & 59.4 \\
\hline \multicolumn{2}{|c|}{ Branch, Immobile } & 1.7 & 0,9 & 1.8 & 2.4 & 1.6 & 2.6 & 3.1 \\
\hline \multirow{2}{*}{ Total } & Percentage & 100.0 & 100.0 & 100.0 & 100.0 & 100.0 & 100.0 & 100.0 \\
\hline & Billion Yen & 111,624 & 44,373 & 25,283 & 19,503 & 8,702 & 2,597 & 7,578 \\
\hline \multicolumn{2}{|c|}{ Regional share (\%) } & 100.0 & 39.7 & 22.6 & 17.5 & 7.8 & 2.3 & 6.8 \\
\hline
\end{tabular}

Source: Ministry of Finance, Statistics Monthly, No. 608, Dec. 2002, Japan.

Notes: ASEAN 4; Indonesia, Malaysia, Philippines and Thailand.

NIEs 4; Hong Kong, Korea, Singapore and Taiwan.

Appendix 2. FDI of the NIEs by region, in the middle of 1990s (percentage)

\begin{tabular}{lcccc|cc}
\hline & Asia & EU & Oceania & NAFTA & Latin America & Others \\
\hline Singapore & 55.5 & 7.7 & 3.2 & 6.6 & & 26.7 \\
Thailand & 50.2 & 18.4 & 1.4 & 17.3 & & 12.7 \\
Taiwan & 55.7 & 0.3 & 0.5 & 8.0 & 24.5 & 1.0 \\
Korea & 44.9 & 15.3 & 2.3 & 31.5 & 4.0 & 2.0 \\
\hline
\end{tabular}

Source: Dept. of Statistics, Statistical Yearbook, Singapore, 1995. Bank of Thailand, Annual Economic Report 1995. Bank of Korea, Overseas Direct Investment Statistics, 1997. Ministry of Economy, Taiwan, Foreign Statistics Monthly, 1997.

Note: Singapore; cumulative stock in 1994, Thailand; flow in 1995, Taiwan and Korea; flow in 1996. 